
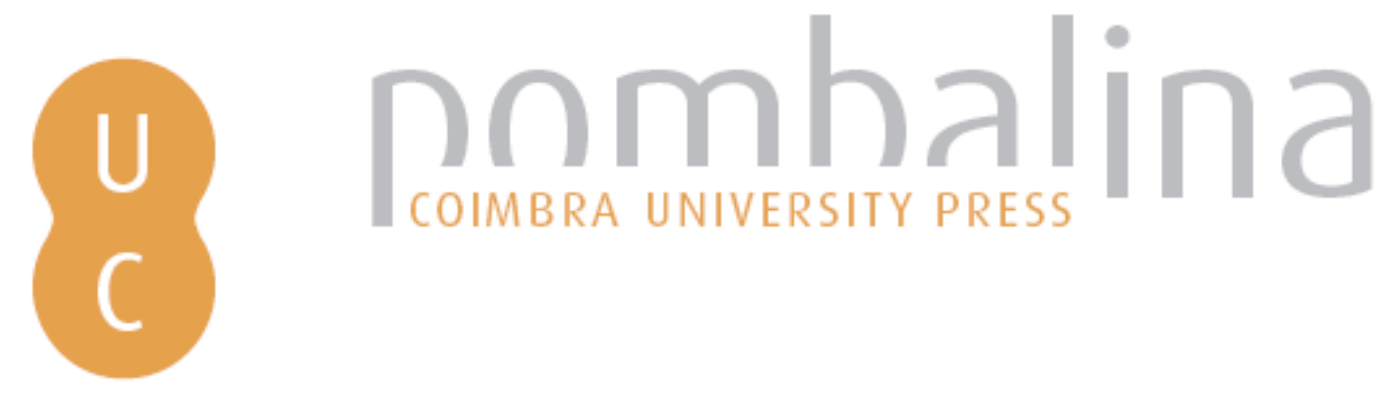

\title{
Anunciar alimentos e seduzir consumidores: a publicidade na revista llustração
} (1926-1939)
Autor(es):
Braga, Isabel M. R. Mendes Drumond
Publicado por: Imprensa da Universidade de Coimbra
URL
persistente:
URI:http://hdl.handle.net/10316.2/45234
DOI:
DOI:https://doi.org/10.14195/978-989-26-1721-3_7
Accessed : $\quad$ 26-Apr-2023 15:32:34

A navegação consulta e descarregamento dos títulos inseridos nas Bibliotecas Digitais UC Digitalis, UC Pombalina e UC Impactum, pressupõem a aceitação plena e sem reservas dos Termos e Condições de Uso destas Bibliotecas Digitais, disponíveis em https://digitalis.uc.pt/pt-pt/termos.

Conforme exposto nos referidos Termos e Condições de Uso, o descarregamento de títulos de acesso restrito requer uma licença válida de autorização devendo o utilizador aceder ao(s) documento(s) a partir de um endereço de IP da instituição detentora da supramencionada licença.

Ao utilizador é apenas permitido o descarregamento para uso pessoal, pelo que o emprego do(s) título(s) descarregado(s) para outro fim, designadamente comercial, carece de autorização do respetivo autor ou editor da obra.

Na medida em que todas as obras da UC Digitalis se encontram protegidas pelo Código do Direito de Autor e Direitos Conexos e demais legislação aplicável, toda a cópia, parcial ou total, deste documento, nos casos em que é legalmente admitida, deverá conter ou fazer-se acompanhar por este aviso.

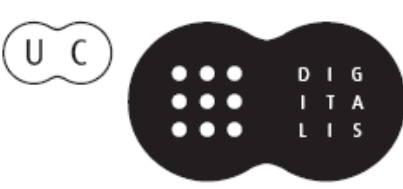


Carmen Soares

Gilene da Silva Gomes Ribeiro

(coords.)

\section{Mesas \\ LUSO-BRASILEIRAS}

\section{ALIMENTAÇÃO, SAÚdE \& GULTURA}

\section{VOLUME I}

IMPRENSA DA UNIVERSIDADE DE COIMBRA COIMBRA UNIVERSITY PRESS

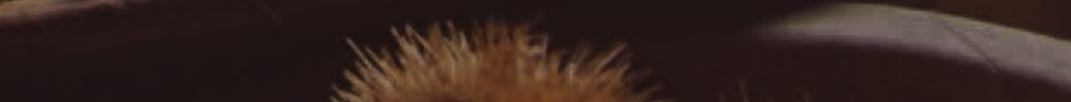




\title{
Anunciar alimentos e seduzir consumidores: A PUBLICIDADE NA REVISTA ILUSTRAÇÃO ( I 926 - I 939)
}

\author{
(To advertise food and seduce consumers: advertising \\ in the magazine Ilustração (1926-1939))
}

\author{
Isabel M. R. Mendes Drumond Braga \\ Universidade de Lisboa, Faculdade de Letras e CIDEHUS_UE \\ (isabeldrumondbraga@hotmail.com)
}

Resumo: Enquanto objeto de estudo, a publicidade só recentemente começou a ocupar os historiadores depois das chamadas de atenção de José Tengarrinha e de A. H. de Oliveira Marques. Posteriormente, foram aparecendo alguns trabalhos que aproveitaram os anúncios publicados em jornais e revistas oitocentistas, designadamente em relação a aspetos tão diversos como a alimentação, a saúde, a higiene e os cosméticos, sem esquecer o vestuário e o recheio das casas. Partir da publicidade de produtos alimentares inserida na revista Ilustração (1926-1939) e percecionar os públicos a que era dirigida, bem como as técnicas utilizadas para seduzir os consumidores, visa entender a maneira como os anunciantes divulgavam os seus produtos mas também os constrangimentos de uma época marcada por dificuldades económicas nas vésperas da II Guerra Mundial. O que se anunciava? Como se anunciava? Quais as características dos anúncios? Em que parte da revista apareciam e que tamanho tinham? O que transmitiam as imagens? Que percentagem ocupavam os anúncios relativos aos produtos alimentares, face ao total dos que eram publicados? Eis algumas das questões que se irão abordar neste estudo que visa contribuir para melhor conhecer a relação entre alimentação e saúde no Portugal de então.

PALAVRas-ChaVe: alimentação, consumidores, Ilustração, Portugal, publicidade, século XX.

Aвstract: As object of study, advertising has only recently begun to attract historians after José Tengarrinha and A. H. de Oliveira Marques had called our attention to it. Later on, some works emerged which were drawn from ads published in newspapers and magazines from the nineteenth century, namely with regard to such diverse aspects such as food, health, hygiene and cosmetics, not to mention clothing and household contents. We will draw from food advertising included in the magazine Ilustração (1926-1939) and identify the public targeted, as well as the techniques used to seduce consumers. Thus, we aim to understand the way advertisers publicised their products and also the constraints of a time marked by economic difficulties on the eve of World War II. What was advertised? How was it 
advertised? What are the characteristics of the ads? In which part of the magazine were they included and what size did they have? What was conveyed by the images? What percentage occupied the ads regarding food products, compared to the total products being published? These are some of the questions that will be approached in this study to help better understand the relationship between diet and health in Portugal at that time.

KEYWORDs: advertising, consumers, food, Ilustração, Portugal, $20^{\text {th }}$ century.

A partir da publicidade incluída na revista Ilustração (1926-1939) pretende proceder-se à análise e à interpretação dos anúncios de bens e serviços relacionados com a alimentação a partir de uma perspetiva que interliga história e publicidade, na conjuntura política-económica que antecedeu a II Guerra Mundial. Mais do que qualificar as obras, integrando-os em categorias, neste caso a revista e os anúncios ali publicados, importa, como salientou Roger Chartier para a Época Moderna, percecionar as intenções de quem escreveu e divulgou e aferir a receção por parte dos leitores, o que nem sempre constitui uma tarefa fácil ${ }^{1}$. Efetivamente, as revistas generalistas, sobretudo as de ampla tiragem, foram-se tornando objetos indispensáveis a públicos tão diferentes como homens de negócios, senhoras da sociedade, mães de família e jovens em busca de moda. Coexistiram com outras que se dedicavam a matérias especializadas vocacionadas para públicos específicos ${ }^{2}$. $\mathrm{O}$ aumento do número de periódicos teve uma relação direta com a alfabetização crescente das populações ${ }^{3}$, consequentemente, a publicidade publicada era relevante quer como fonte de receita para o impresso quer como forma de moldar os comportamentos da população, em especial quando potencializada por imagens sugestivas e textos explicativos.

\section{i. Publicidade e História}

A publicidade apareceu timidamente nos periódicos setecentistas, designadamente na Gazeta de Lisboa $a^{4}$, continuou a desenvolver-se ao longo dos séculos XIX e XX, ficando plasmada em azulejos, objetos diversos, cartazes, bilhetes-postais e, naturalmente, em periódicos, sem esquecer a rádio e a televisão para épocas mais próximas ${ }^{5}$. Apesar de a sua afirmação ser lenta e

1 Chartier 1987, Chartier 1996.

2 Martins 2001: 97, 102, passim.

${ }^{3}$ Chartier 1990: 113-161.

${ }^{4}$ Sobre a publicidade na Gazeta de Lisboa, cf. Braga 2001: 465-565, Belo 2001, Soares 2008.

5 Sobre a publicidade nos vários suportes, cf. Estrela 2002-2004. Cf. também, 300 Anos do Cartaz em Portugal 1975-1976; Pereira 1998; O Vício da Liberdade. Colecção Berardo. Arte e Desenhos Publicitários 2003; A Publicidade no Azulejo 2004, Trindade 2008. Sobre a publicidade em 
progressiva, já era uma constante em alguns jornais e revistas oitocentistas, sem esquecer os que eram dedicados especificamente aos anúncios, caso do Jornal de Annuncios, Rio de Janeiro, 1821; O Periódico dos Anúncios, Porto, 1827; Jornal dos Anúncios, Lisboa, 1835; Folha de Anúncios, Porto, 1835 e Grátis, Lisboa, 1836. Para o século seguinte, e limitando-nos às primeiras décadas, temos outros jornais igualmente dedicados em exclusivo à publicação de anúncios, caso de O Reclamo, Lisboa, 1913-1914; A Propaganda, Lisboa, 1915; A Cidade, Lisboa, 1921; A Gazeta Anunciadora, Lisboa, 1921 e Portugal Anunciador, Lisboa, $1927^{6}$.

Enquanto objeto de estudo, a publicidade só recentemente começou a ocupar os historiadores portugueses depois das chamadas de atenção de José Tengarrinha e de A. H. de Oliveira Marques. O primeiro interessou-se pela publicidade enquanto fonte de receitas dos jornais ${ }^{7}$ e o segundo pelo potencial destas fontes para o estudo do quotidiano, considerando a publicidade uma ciência auxiliar da História ${ }^{8}$. Posteriormente, foram aparecendo alguns trabalhos que aproveitaram os anúncios publicados em jornais e revistas dos séculos XVIII a XX, designadamente em relação a aspetos tão diversos como a alimentação ${ }^{9}$, as atividades desenvolvidas pelos negros ${ }^{10}$, a saúde, a higiene e os cosméticos ${ }^{11}$, sem esquecer o vestuário e o recheio das casas ${ }^{12}$ ou as imagens da mulher ${ }^{13}$. Refiram-se ainda os trabalhos que estudaram a publicidade em termos globais, durante algum período cronológico ${ }^{14}$.

Contendo uma dimensão económica e outra de comunicação, a publicidade deverá ser capaz de chamar a atenção, despertar o interesse, criar o desejo e conduzir à ação de adquirir um determinado bem ou serviço. Assim, os anúncios deverão informar de forma motivadora para que os recetores se sintam incentivados a comprar o que é anunciado. No entanto, ao contrário do que acontece na atualidade, na primeira metade do século XX, nem todos

objetos de porcelana, cf. Segundo Leilão Vista Alegre 1998: 69-73; Terceiro Leilão Vista Alegre 1999: 67-74; Quarto Leilão Vista Alegre 2000: 55-64; Quinto Leilão Vista Alegre 2002: 47-53; Sexto Leilão Vista Alegre 2003: 43-50; Sétimo Leilão Vista Alegre 2004: 53-61; Oitavo Leilão Vista Alegre 2007: 45-48; Nono Leilão Vista Alegre 2009: 61-67. Para o Brasil, cf. Os "Reclames" de Fulvio Pennacchi: Primórdios da Propaganda Brasileira 2005. Para França, cf. L'Art dans la Pub 2000, Bargiel 2004. Para Itália, cf. Pubblicità Eं Arte. Grafica Internazionale dall'Affiche alla Pop Art 2007.

${ }^{6}$ Dados apresentados com base em Marques 1981: 546.

7 Tengarrinha 1989: 223-227.

${ }^{8}$ Marques 1981.

9 Braga 2000, Braga 2006: 215-225, Braga 2010. Para o Brasil, cf. El-Kareh, Bruit 2004: 1-23.

10 Menezes 2008: 221-242.

11 Pereira, Pita 1996: 159-168; Pereira, Pita 1998: 29-40; Pita 1998; Braga 2001: 93-125; Braga 2012.

12 Marques 1991: 617-677.

${ }_{13}$ Mota-Ribeiro 2002: 145-164.

${ }^{14}$ Braga, Oliveira 2008: 415-436; Tadeu 2007: 315-340. Para o Brasil, cf. Campos 2009 e Rodrigues 2015. 
os anúncios eram particularmente apelativos e claros, o que contrastava com outros impregnados de forte carácter informativo recorrendo a textos densos, semelhantes a pequenos artigos. $\mathrm{O}$ facto de muitos serem a preto e branco e nem sempre conterem imagens também não facilitava o apelo.

\section{A Conjuntura no Período entre as duas Guerras}

Nos anos 1920 e 1930, ou seja, entre as duas guerras, o cenário europeu era pouco animador. A I Guerra Mundial terminou em novembro de 1918 e Portugal viu-se reconhecido entre os vencedores, sendo confirmada a posse das suas colónias. Nos anos que se seguiram ao fim do conflito, o país continuou a viver as sequelas da guerra, com inflação, desvalorização da moeda, falência de bancos e empobrecimento generalizado ${ }^{15}$. A conjuntura era, consequentemente, bastante desfavorável do ponto de vista económico. E a situação não melhorou nos anos seguintes nem dentro nem fora de Portugal.

A grande crise económica que se seguiu a 1929 levou os Estados europeus ao desenvolvimento de uma mentalidade autárcica, entrincheirando-se nas suas fronteiras económicas, fechando-se a contactos com o exterior e aumentando as barreiras alfandegárias. Esse nacionalismo económico fez reavivar velhos ódios e inimizades que se agudizaram com a subida ao poder na Alemanha de Hitler (1933) que, no seu livro Mein Kampf (1923), apresentara um programa claramente expansionista: vingar a derrota sofrida em 1918, criar uma "Grande Alemanha", constituída por todos os povos de sangue germânico e criar um "espaço vital" alemão, o que implicaria uma expansão em direção ao Leste.

Em Portugal, o Estado Novo manteve a aliança com a Inglaterra, mas também estreitou relações com países onde vigoravam regimes de tipo fascista, como por exemplo a Itália e a Alemanha. No caso da Espanha, Salazar apoiou o levantamento militar de 1936 (feito contra um governo de coligação socialista e comunista), que conduziu à Guerra Civil e à vitória final do general Franco, ou seja, à institucionalização de um regime aparentado com o de Portugal, durante a II Guerra Mundial. A atitude de Salazar foi de neutralidade pois, embora ideologicamente se achasse próximo da Alemanha e da Itália, não pretendia romper a duradoura ligação de Portugal com a Inglaterra. Ainda assim, havia no país partidários quer da Alemanha quer da Inglaterra ${ }^{16}$.

Portugal não era autossuficiente em termos alimentares, dependia do abastecimento exterior de muitos géneros e a política agrícola do Estado Novo não conseguiu revelar-se eficaz, apesar de, exatamente nos anos 30, a

15 Marques 1991a: 709-717; Martinez 2001: 135-319; Rosas 2009: 245-406; Oliveira 2011: $185-225$.

${ }^{16}$ Sobre a posição política de Salazar face à II Guerra Mundial, cf. Meneses 2010: 249-357. 
chamada "Campanha do Trigo" ter tido inicialmente resultados promissores, com o aumento da área de produção, que terminaram na época do início da II Guerra Mundial. Ou seja, o conflito armado apenas tornou mais evidentes as vulnerabilidades estruturais da economia portuguesa ${ }^{17}$.

Se é melhor conhecida a situação durante a II Guerra Mundial, no que se refere às condições económica e alimentar ${ }^{18}$, a época anterior merece igualmente atenção. Recorde-se que, entre as duas Guerras Mundiais, concretamente na década de 1930, surgiram vários livros de receitas destinados a públicos femininos menos exigentes tais como, por exemplo, algumas das obras de Rosa Maria, pseudónimo utilizado por Gaspar de Almeida; de Branca Miraflor e de Estela Brandão ${ }^{19}$. Paralelamente, a I Guerra Mundial implicou uma simplificação das refeições, aliada à escassez dos géneros alimentares e ao consequente racionamento, o que levou a alterações nos hábitos das populações, com a diminuição de pratos, pondo fim à longa herança de sumptuosas refeições quotidianas entre os abastados. A II Guerra Mundial consolidou essa realidade ${ }^{20}$. O mesmo aconteceu na Itália de Mussolini ${ }^{21}$ e em Espanha, um espaço que conheceu uma situação mais agravada em resultado da Guerra Civil ${ }^{22}$, sem esquecer a Alemanha, mesmo após a guerra ${ }^{23}$.

\section{Para uma Breve Caracterização da Revista e dos seus Públicos}

A revista Ilustração apresentou-se como uma publicação quinzenal que vinha colmatar uma lacuna, na medida em que no país, ao contrário do que se verificava em França, na Alemanha, em Inglaterra, nos Estados Unidos da América e no Brasil, não existia nenhuma, segundo o autor não identificado da abertura da publicação, presumivelmente o seu diretor, João da Cunha de Eça, que reforçou: "onde quer que a civilização tenha na verdade afeiçoado o Homem a necessidade em que o espírito predomina, as ilustrações e os magazines pululam, podendo bem dizer-se que ao lado da imprensa diária

17 Nunes, Brito 1992: 319-321; Rosas 1994: 322-327. Para se fazer um paralelo com o Brasil, designadamente com São Paulo, cf. Cytrynowicz 2000: 52-122, 230-252.

18 Braga 2015: 1-23.

19 Braga 2008; Braga 2015; Braga 2015.

20 Sobre esta realidade, cf. Marques 1991b: 617-626.

${ }^{21}$ Sobre a Itália de Mussolini, nos anos 30, e em concreto sobre o pouco entusiasmo a nível local pelo fascismo, cf. Corner 2015:221-250, passim. Outras relações entre alimentação e guerra podem ver-se, por exemplo, em Mafai 2008, Helstosky 2004.

22 Sobre os problemas da fome durante a Guerra Civil Espanhola, cf., de entre outros, Romero Samper 2013: 159-190. Não obstante, a propaganda política recorria ao turismo político, investindo na hospitalidade dos visitantes, os quais eram controlados politicamente. Sobre esta matéria, cf. García 2006: 287-308.

${ }^{23}$ MacDonogh 2007: 110-119, passim. 
eles crescem e se desenvolveram com a exuberância duma floresta tropical"24. Conhecerá outros diretores até 1939, designadamente João de Sousa Fonseca, António Ferro e Artur Brandão.

A nova publicação contou com um enorme leque de colaboradores, nele se incluindo muitos nomes cimeiros da cultura portuguesa de então, como por exemplo, Afonso Lopes Vieira, Albino Forjaz de Sampaio, António Sérgio, Aquilino Ribeiro, Armando Cortesão, Carlos Selvagem, Henrique Lopes de Mendonça, Jaime Cortesão, José Leite de Vasconcelos, Júlio Dantas, Raul Brandão e Raul Lino, sem esquecer o brasileiro Afrânio Peixoto. Lugar ainda para duas mulheres a escritora Helena de Aragão (1880-1961) e a publicista Maria Fernanda Costa. A primeira, que chegou a utilizar o pseudónimo de Agarena de Leão, compôs obras literárias - poéticas e em prosa - e obras musicais, fundou e dirigiu as revistas Eva (1925) e Fémina (1933), além de ter também dirigido, durante alguns anos, a Modas e Bordados. Foi redatora do jornal O Mundo e colaborou em outras revistas como a Ilustração Portuguesa e a Civilização e nos jornais Século da Noite e O Primeiro de Janeiro ${ }^{25}$. A segunda, da qual quase nada se sabe, dirigiu o Almanaque Bertrand, fundado pelo pai.

A Ilustração, cujo primeiro exemplar foi publicado a 1 de janeiro de 1926 , custava $4 \$ 00$ por cada número avulso, $7 \$ 00$ por mês ou $21 \$ 00,42 \$ 00$ ou $84 \$ 00$, caso os leitores optassem por assinaturas trimestrais, semestrais ou anuais, respetivamente. Estes valores eram apenas para os residentes em Portugal continental e nas ilhas, pois os que vivessem na África ocidental, na oriental, na Índia, em Macau, em Timor ou no estrangeiro teriam que pagar preços mais altos. A revista começou por apresentar 36 páginas, no número um, mas foi aumentando de tamanho. No 12, já contava com 46 e no 24 , do referido ano de 1926, atingiu as 70 . As capas dos 24 primeiros números contaram quase todas com figuras femininas. A situação manteve-se assim durante algum tempo. Porém, a partir de 1933, passou a incluir igualmente figuras cimeiras da História de Portugal de várias épocas, num esforço coordenado do Estado Novo no sentido de valorizar os heróis nacionais. Dessa forma, tornou-se visível o empenho do Secretariado da Propaganda Nacional, criado nesse mesmo ano, no sentido de interferir em todas as áreas da produção cultural portuguesa e, não esqueçamos, uma delas consistia exatamente em regular as relações da imprensa com os poderes do Estado ${ }^{26}$. Nos anos seguintes, a revista só ultrapassou as 40 e poucas páginas no último número, tendo chegado a ficar mais pequena especialmente nos últimos anos da década de 30. Mas, em 1931, o último volume contou, pela primeira e única

\footnotetext{
${ }^{24}$ Ilustração, n. ${ }^{\text {1, Lisboa, } 1}$ de janeiro de 1926.

25 Oliveira 1981: 71, Dias 2005: 385. Sobre a revista Eva, cf. Gomes 2011.

26 Para uma síntese dessa matéria, cf. Ó 1992: 396-398, Ó 1999, Acciaiuoli 2013.
} 
vez nesta década, com 70 páginas. Foi também nesse ano que aumentou de preço, passando o número avulso a custar $5 \$ 00$, situação que continuará até ao final da publicação em dezembro de 1939, quando os efeitos da II Guerra Mundial se fizeram sentir. Efetivamente, no último número dessa primeira série, pode ler-se que a publicação seria suspensa devido ao encarecimento das gravuras e à dificuldade de importar papel couché, que não se fabricava em Portugal. Mais se informou que "reaparecerá quando a anormalidade que o mundo atravessa o permitir"27.

Recordemos que durante a II Guerra Mundial, o racionamento e a falta generalizada de alguns produtos era bastante evidente mesmo para Estados que, como Portugal, não se envolveram diretamente no conflito. $\mathrm{O}$ país não era autossuficiente, dependia do abastecimento exterior de muito géneros, provenientes de países beligerantes e ocupados, conhecia uma permanente irregularidade de fornecimentos, agravada pelos problemas que a guerra provocava ao nível da produção e do transporte e a inflação aumentava. Assim, também se compreende que se anunciasse menos, até porque havia menos bens disponíveis para consumo, especialmente os que eram importados ${ }^{28}$.

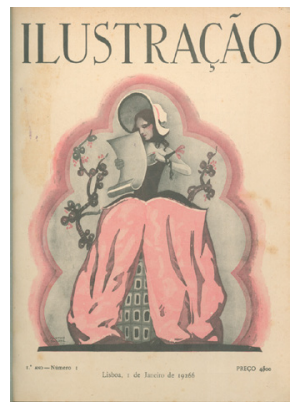

Figura 1: Capa do primeiro número da Ilustração

A revista apresentou-se organizada em diversas seções, que foram tendo designações diferentes ao longo do período de publicação. Logo no início podem encontrar-se as de crónica social, moda, desporto, vida colonial, vida científica, páginas infantis, de humor, contos, além de seções dedicadas a teatro, cinema, música e passatempos. Incluía matérias nacionais e estrangeiras e publicidade nas primeiras e nas últimas páginas. Os anúncios eram

27 Ilustração, n. ${ }^{\circ}$ 336, Lisboa, 16 de dezembro de 1939. A revista reaparecerá em 1961. O primeiro número depositado na Biblioteca Nacional de Portugal e na hemeroteca digital é o 358, pelo que se presume ter havido 21 anteriores. Tornou-se anual, manteve inicialmente o preço de $5 \$ 00$ por volume e começou por ser dirigida por Vitorino Nemésio, mas desaparecerá em dezembro de 1975.

28 Braga 2015: 15-16. 
de tamanho muito diversificado, uma vez que temos os de página inteira, de meia página a par de alguns com menos de 3,5 por 4,5 centímetros. A maioria era a preto e branco e nem todos utilizavam imagens, como antes se notou. Embora a revista tenha insistido que tinha a maior tiragem em Portugal, consequentemente era um caso de sucesso, não indicou quantos exemplares eram publicados. No entanto, as várias seções forneciam informações acerca de pessoas e eventos de requinte, davam conselhos práticos às mulheres que tinham tempo, possibilidades e interesse em cuidar de si mesmas e, naturalmente, em gerir as suas casas, mas é plausível que as que tinham menos meios também gostassem de folhear e ler sobre vidas a que eventualmente aspirariam. Tenhamos em conta que Portugal era um país com elevadas taxas de analfabetismo - 61,8 por cento em 1930, apesar das discrepâncias entre homens e mulheres e entre as cidades e os meios rurais ${ }^{29}$ - e com uma burguesia de reduzida amplitude, logo quer os artigos quer a publicidade da revista só atingiriam uma minoria da população.

Pelas matérias tratadas e pela publicidade incluída podemos conjeturar que o público era composto por homens e mulheres dos grupos médios e altos da sociedade. No que se refere à publicidade, no primeiro ano, foram dados à estampa 479 anúncios. E se a maioria, 122, ou seja, 25,5 por cento, se referiu a produtos de higiene e beleza, cujo público-alvo era as mulheres e muito secundariamente os homens, não podemos esquecer que entre esses produtos contam-se lâminas e máquinas de barbear, também teremos que ter em atenção outras realidades. Se tivermos em conta outras tipologias, designadamente automóveis e acessórios aos mesmos destinados, como alarmes, baterias, combustíveis, óleo, pneus, tintas e velas, podemos verificar que ocuparam 19,4 por cento, se a estes juntarmos publicidade relativa a máquinas industriais, bancos, seguros, tabaco e até algum material de escritório, para uso pessoal, como canetas, sem esquecer a categoria outros, na qual temos, por exemplo, ateliers de arquitetura, poderemos presumir que a maior parte dos leitores da Ilustração era do sexo masculino, com capacidades de leitura e escrita e com algum ou bastante poder económico. À medida que os anos foram avançando, as seções dedicadas às mulheres e a própria publicidade, em especial a de produtos de higiene e beleza e a de livros para cuidar da casa e dos filhos - parecem demonstrar que o número de leitoras estava em crescimento, o que não teve repercussão na publicidade dedicada ao vestuário e aos acessórios, sempre escassa, como se demonstrará mais adiante. Não obstante ser imprudente fazer uma divisão taxativa entre género e publicidade,

29 Destaque-se a cidade de Lisboa, onde os que sabiam ler eram na ordem dos 62,1 por cento (68,8 por cento no caso dos homens e 56 por cento no caso das mulheres) contra o Porto com 56,7 por cento ( 67,1 por cento de homens e 47,9 por cento de mulheres), igualmente em 1930. Cf. Marques 1991c: 519-520. 
na época em análise essa fronteira era bastante mais marcada do que em períodos posteriores, pois os papéis e as especificidades de cada sexo também o eram. Finalmente, refira-se que a Ilustração contará com a concorrência de revistas femininas, designadamente a Modas e Bordados (publicada desde 1912), a Eva, fundada em 1925, e a Fémina (aparecida em 1933).

\section{A Publicidade na Ilustração}

Depois de uma primeira prospeção, decidimos dividir os anúncios em 16 categorias, de modo a termos uma perspetiva ampla do tipo de bens e serviços que a Ilustração dava a conhecer aos leitores. Após o levantamento efetuado, tornaram-se evidentes algumas questões, designadamente a escassa representatividade de alguns itens, caso das joias e do vestuário e acessórias. A situação contrastou com as categorias beleza e higiene e eletrodomésticos e acessórios para casa, não obstante também interessaram aos homens, embora de forma muito menos relevante. Outro aspeto a salientar referiu-se ao peso dos anúncios dessa última categoria. Recorde-se que, como veremos em outro momento, esse tipo de bens era ainda extremamente escasso. Até 1930, a publicidade relativa a carros e acessórios para os mesmos teve um peso considerável que se tornou residual a partir de então. Se bem que o público-alvo tenha sido os homens, houve alguns anúncios esporádicos que colocaram mulheres ao volante. Note-se que os cuidados com a rede vial aumentaram a partir de 1926, que a maior parte dos veículos particulares eram importados dos Estados Unidos da América e, muito menos, de França, Grã-Bretanha, Itália e Alemanha, sem esquecer que, em 1931, para uma população de 6380687 pessoas havia 15154 quilómetros de estradas e 32698 veículos, ou seja, um carro para cada 195 pessoas. Se pensarmos apenas nos ligeiros, em 1930, importaram-se 2611, e em 1939, o número ascendeu a 3087, demonstrando que os efeitos da guerra já se começavam a sentir, uma vez que em 1937, a importação chegara aos $4060^{30}$. Curiosamente, o decréscimo acentuado da publicidade aos automóveis foi compensado com o aumento significativo dos anúncios de livros, almanaques e revistas. Muito irregulares foram as presenças de outras categorias como bancos, seguros, máquinas industriais e até tabaco. No item outros, os bens e serviços foram variando bastante ao longo dos anos, contando-se, por exemplo, serviços aéreos (designadamente a ligação Lisboa-Madrid), de arquitetura e de astrologia, feiras internacionais, cursos de natação, excursões ao Algarve, a Marrocos e a Constantinopla e ainda contratação de pessoal para os Caminhos de Ferro de Portugal, a par de alguns bens como microscópios, material cirúrgico e relógios.

30 Vieira 1980: 71, 81. 
Isabel M. R. Mendes Drumond Braga

\begin{tabular}{|c|c|c|c|c|c|c|c|c|c|c|c|c|c|c|c|}
\hline Anos & 1926 & 1927 & 1928 & 1929 & 1930 & 1931 & 1932 & 1933 & 1934 & 1935 & 1936 & 1937 & 1938 & 1939 & Total \\
\hline Alimentação & 16 & 20 & 9 & 26 & 18 & 84 & 46 & 37 & 40 & 10 & 11 & 24 & 9 & 0 & 350 \\
\hline Beleza e Higiene & 122 & 22 & 23 & 79 & 56 & 64 & 39 & 20 & 31 & 43 & 48 & 43 & 4 & 0 & 594 \\
\hline Saúde & 62 & 50 & 37 & 52 & 74 & 54 & 65 & 47 & 47 & 44 & 78 & 89 & 89 & 50 & 838 \\
\hline $\begin{array}{l}\text { Vestuário e } \\
\text { Acessórios }\end{array}$ & 13 & 2 & 7 & 9 & 3 & 5 & 1 & 0 & 0 & 1 & 0 & 1 & 0 & 1 & 43 \\
\hline Joias & 11 & 1 & 0 & 0 & 0 & 2 & 1 & 0 & 0 & 0 & 0 & 0 & 1 & 0 & 16 \\
\hline Livros e Revistas & 50 & 105 & 97 & 76 & 130 & 174 & 480 & 621 & 378 & 629 & 498 & 505 & 368 & 461 & 4572 \\
\hline $\begin{array}{c}\text { Material Escolar e } \\
\text { de Escritório }\end{array}$ & 21 & 43 & 44 & 20 & 10 & 27 & 46 & 47 & 56 & 48 & 50 & 56 & 46 & 47 & 561 \\
\hline $\begin{array}{l}\text { Móveis e } \\
\text { Decoração }\end{array}$ & 9 & 2 & 1 & 0 & 2 & 22 & 11 & 0 & 0 & 1 & 1 & 2 & 1 & 2 & 54 \\
\hline $\begin{array}{c}\text { Eletrodomésticos } \\
\text { e Acessórios para } \\
\text { a Casa }\end{array}$ & 9 & 15 & 21 & 54 & 37 & 30 & 27 & 17 & 5 & 4 & 14 & 16 & 14 & 0 & 263 \\
\hline $\begin{array}{c}\text { Material } \\
\text { Fotográfico }\end{array}$ & 11 & 8 & 6 & 9 & 10 & 11 & 13 & 1 & 0 & 0 & 0 & 0 & 0 & 1 & 70 \\
\hline $\begin{array}{c}\text { Automóveis, Peças } \\
\text { e Acessórios }\end{array}$ & 93 & 85 & 148 & 113 & 108 & 30 & 9 & 4 & 6 & 4 & 2 & 0 & 0 & 0 & 602 \\
\hline $\begin{array}{l}\text { Máquinas } \\
\text { Industriais }\end{array}$ & 6 & 0 & 2 & 0 & 0 & 0 & 0 & 0 & 0 & 0 & 0 & 0 & 0 & 1 & 9 \\
\hline Tabaco & 14 & 5 & 0 & 0 & 0 & 1 & 1 & 0 & 0 & 0 & 0 & 0 & 0 & 22 & 43 \\
\hline Bancos & 7 & 3 & 5 & 0 & 0 & 4 & 3 & 0 & 0 & 0 & 0 & 0 & 0 & 0 & 22 \\
\hline Seguros & 3 & 0 & 0 & 0 & 0 & 4 & 0 & 0 & 13 & 12 & 12 & 12 & 12 & 12 & 80 \\
\hline Outros & 32 & 18 & 27 & 15 & 11 & 15 & 10 & 7 & 5 & 18 & 16 & 1 & 2 & 2 & 179 \\
\hline Total & 479 & 379 & 427 & 453 & 459 & 527 & 752 & 801 & 581 & 814 & 730 & 749 & 546 & 599 & 8296 \\
\hline
\end{tabular}

Quadro 1: A Publicidade na Revista Ilustração (1926-1939) 


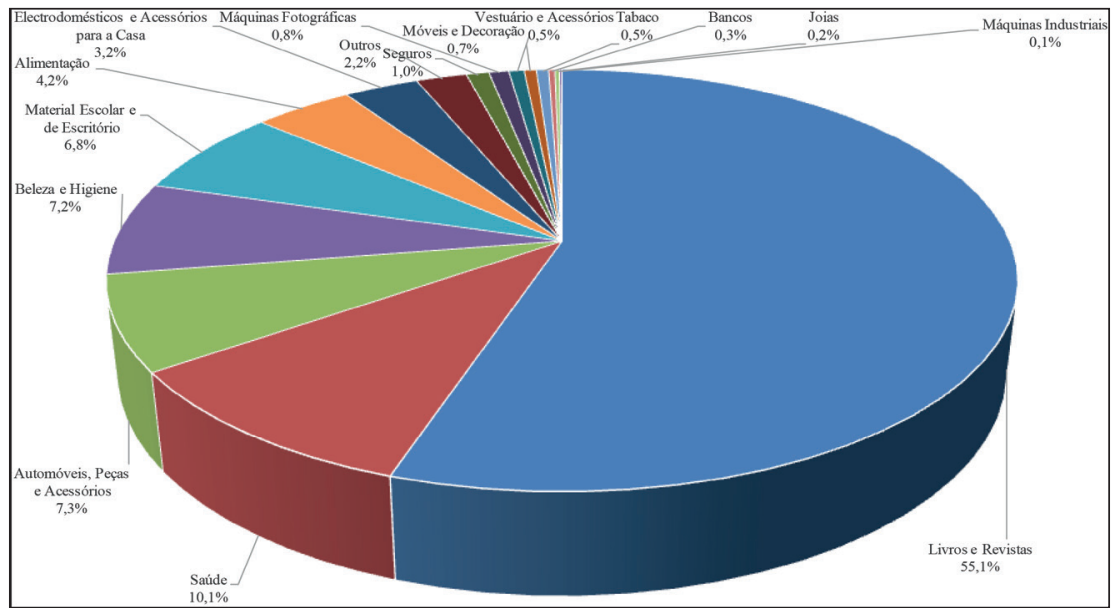

Gráfico 1: Tipologia da Publicidade na Revista Ilustração (1926-1939)

Alguma publicidade não ficou alheia à época do ano. Há uma clara insistência nas máquinas fotográficas no período de férias, o que também nos indicia algum poder económico, não só para as adquirir como para usufruir do descanso anual fora de casa e inteiramente dedicado ao lazer. Efetivamente, em Portugal, em 1934, deu-se a publicação do Guia de Hotéis e Turismo em Portugal, da autoria de Fernando Soares, um texto em português, inglês, francês e castelhano, no qual se apresentam plantas e mapas, praias, termas e estâncias de turismo, as distâncias em quilómetros entre Lisboa e diversas localidades do país, a lista dos monumentos classificados além das companhias de caminho-de-ferro e de alguma publicidade ${ }^{31}$. O turismo, que apresentava uma dupla dimensão, económica e prática social e cultural ${ }^{32}$, foi acarinhado pelo Estado Novo ${ }^{33}$. Entretanto, a publicação de brochuras, cartazes, folhetos e guias diversos, destinados a públicos distintos, incluindo estrangeiros, foi tendo lugar. Destaque-se o Guia de Portugal, cujos primeiros dois volumes saíram em 1924 e 1927, sob a tutela de Raul Proença ${ }^{34}$. É neste contexto inicial ${ }^{35}$, desenvolvido durante o Estado Novo, nomeadamente pela mão de António Ferro, que se intensifica o interesse pelos costumes locais e por uma certa "portugalidade". No entanto, na década de 30, o parque hoteleiro era precário tanto a nível das instalações como dos serviços prestados por pessoal não qualificado. Refira-se, por exemplo, que o

\footnotetext{
${ }^{31}$ Soares 1934.

32 Sobre o interesse económico do turismo, cf., por exemplo, Borsay 2006 e Battilani 2009: 23-51.

33 Sobre as políticas estatais de promoção turística e sobre a relação entre as ditaduras e o turismo na Europa, cf. a síntese de Faralo e Rodríguez-López 2013: 124-146.

${ }^{34}$ Sobre esta matéria, cf. Pina 1988: 43-63 e Lousada 2010: 65-75.

35 Sobral 2007: 40-43.
} 
primeiro curso de gerentes de hotéis datou de 1931 e que em 1933 se promoveu uma exposição inaugurada em Lisboa sobre o Hotel Modelo, na qual foram apresentados oito projetos arquitetónicos de hotéis regionais (Minho, Douro, Trás-os-Montes, Beira Alta, Beira Baixa, Estremadura, Alentejo e Algarve), o que acabaria por dar origem à conceção das pousadas, a partir de $1940^{36}$. Não é, assim, de estranhar que as máquinas fotográficas fossem objetos apreciados, especialmente durante as férias.

Nos primeiros anos de publicação da revista, a partir de setembro, também se insiste no material escolar. Para a década de 30, foram sobretudo os serviços de tipografia, gravação e os materiais para escritório que predominaram, distribuindo-se por todo o ano. Por outro lado, a oferta de livros, alguns dos quais a pensar na formação de crianças e de jovens, mas também de revistas e de anuários foi crescendo, não tendo uma relação direta com a sazonalidade. No primeiro ano da publicação não há nenhuma referência a épocas festivas como a Páscoa e o Natal na publicidade, o mesmo não acontecendo nas páginas dos artigos da revista. Porém, em dezembro de 1927, apareceu, pela primeira vez um anúncio de uma máquina de escrever portátil com a seguinte indicação: "É assim que se deve dar as Boas Festas" 37. De qualquer modo, a relação entre as duas questões nunca foi particularmente marcante.

\section{Bens e Serviços Alimentares na Publicidade da Ilustração}

Entre os 8926 anúncios publicados ao longo dos 14 anos de existência da revista, apenas 350 foram relativos a géneros e serviços ligados à alimentação, representando 4,2 por cento do total. Ao contrário da publicidade dedicada a matérias como beleza e higiene, joias ou até mesmo material fotográfico ou automóveis, os anúncios relativos a produtos alimentares não foram dos mais interessantes nem do ponto de vista da imagem, nem do tipo de informação veiculada, nem mesmo da forma como apelaram ao consumo. Tal como foi habitual na época ou em anos próximos e em outros periódicos, houve algumas tentativas de associar alimentação e saúde fomentando a confusão entre alimentos, medicamentos e suplementos alimentares ${ }^{38}$.

36 Pina 1988: 63, Melo 2001: 250-258.

37 Ilustração, n. ${ }^{\circ}$ 48, Lisboa, 16 de dezembro de 1927.

${ }^{38} \mathrm{Em}$ alguns casos, os anunciantes iam bastante longe. Por exemplo, num anúncio publicado na Ilustração, n. ${ }^{\circ}$ 48, Lisboa, 16 de dezembro de 1927, pode ler-se: "É fácil ser robusto, basta tomar ao pequeno-almoço e ao lanche uma xícara de Banania, o melhor e mais agradável dos alimentos para todas as idades". Tratava-se de um produto francês, à venda em Lisboa, na rua da Prata, 71, 1.․ Não há qualquer referência à composição do mesmo. No ano seguinte, apareceu, por exemplo, o Phoscao, importado por Jerónimo Martins e Filho, o qual podia ser adquirido em mercearias, farmácias e drogarias. Era um produto, definido como alimento, destinado a pessoas saudáveis, doentes, convalescentes, idosos, amas-de-leite e mães que amamentavam. Cf. Ilustração, n. ${ }^{\circ}$ 71, de 1 de dezembro de 1928. 


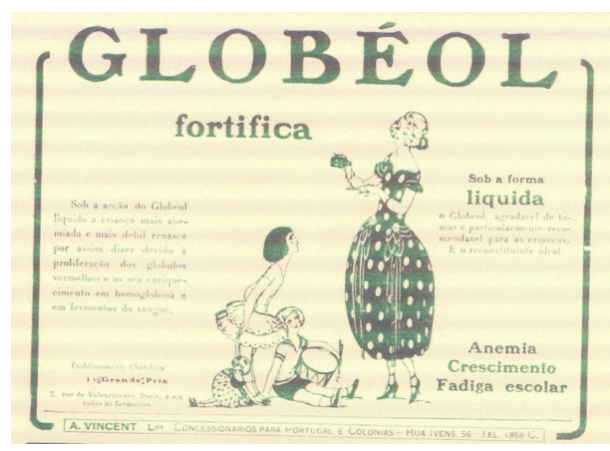

Figura 2: Anúncio de um fortificante alimentar, associando alimentação e saúde Fonte: Ilustração, n. ${ }^{\circ}$ 22, Lisboa, 16 de novembro de 1926.

Ao longo dos anos em análise, podemos verificar que, para todas as matérias, há uma significativa repetição de alguns anúncios. No que se refere aos que envolvem as práticas alimentares, temos um máximo de 84 , em 1931, os quais representaram 15,9 por cento e um mínimo de zero, em 1939. Por seu lado, os produtos e serviços diferentes em cada ano em que foram publicados anúncios, variou entre um máximo de 14, no ano de 1931, e um mínimo de um, em 1935 e 1937. O aumento ou diminuição do número destes não seguiu necessariamente o mesmo ritmo da restante publicidade, como se pode verificar pelos Quadro 2 e Gráfico 2.

\begin{tabular}{|c|c|c|c|c|c|}
\hline Anos & $\begin{array}{c}\text { Total de } \\
\text { Anúncios }\end{array}$ & $\begin{array}{c}\text { Média de } \\
\text { anúncios por } \\
\text { número }\end{array}$ & $\begin{array}{c}\text { Anúncios } \\
\text { relativos a } \\
\text { Alimentação }\end{array}$ & $\begin{array}{c}\text { Anúncios de Bens ou } \\
\text { Serviços Alimentares } \\
\text { Diferentes }\end{array}$ & $\begin{array}{c}\text { Percentagem dos } \\
\text { Anúncios relativos a } \\
\text { Alimentação }\end{array}$ \\
\hline 1926 & 479 & 20 & 16 & 4 & 3,3 \\
\hline 1927 & 379 & 16 & 20 & 3 & 5,2 \\
\hline 1928 & 427 & 18 & 9 & 5 & 2,1 \\
\hline 1929 & 453 & 19 & 26 & 5 & 5,7 \\
\hline 1930 & 459 & 19 & 18 & 4 & 3,9 \\
\hline 1931 & 527 & 22 & 84 & 14 & 15,9 \\
\hline 1932 & 752 & 31 & 46 & 5 & 6,1 \\
\hline 1933 & 801 & 33 & 37 & 6 & 6,6 \\
\hline 1934 & 581 & 24 & 40 & 3 & 1,2 \\
\hline 1935 & 814 & 34 & 10 & 1 & 1,5 \\
\hline 1936 & 730 & 30 & 11 & 3 & 3,2 \\
\hline 1937 & 749 & 31 & 24 & 1 & 1,6 \\
\hline 1938 & 546 & 23 & 9 & 2 & 0 \\
\hline 1939 & 599 & 25 & 0 & 0 & 4,2 \\
\hline Total & 8296 & - & 350 & - & \\
\hline
\end{tabular}

Quadro 2: Anúncios de Bens e Serviços Alimentares na Ilustração (1926-1939) 


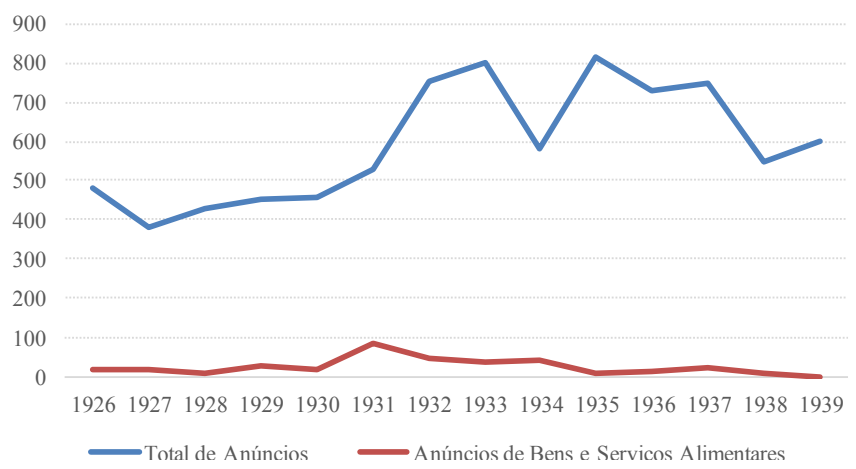

Gráfico 2: Evolução da Publicidade de Bens e Serviços Alimentares em Comparação com o Total da Publicidade da Ilustração (1926-1939)

Passemos a uma análise anual da publicidade acerca de bens e serviços relacionados com a alimentação. Em 1926, dos 16 anúncios apenas um se repetiu 13 vezes e apresentou uma imagem. Trata-se do que publicitou a farinha Phosphatine Falières, produto que deveria ser misturado com leite, destinado a crianças a partir dos sete ou oito meses e também a idosos, designados por velhos, e a convalescentes. De notar as preocupações expressas na publicidade relativa aos produtos lácteos, o que já se verificava em anúncios publicados em outras revistas de datas anteriores ${ }^{39}$. Efetivamente, num período de elevada mortalidade infantil ${ }^{40}$, a existência de alimentos pretensamente equivalentes ao leite materno, com propriedades que favoreceriam o crescimento e desenvolvimento saudáveis era, naturalmente, motivo de interesse para as mães, frequentemente explorado pela publicidade. E, recorde-se, que o leite em pó foi introduzido em Portugal em 1923, por influência de pediatras, sendo da marca $\mathrm{Nestle}^{41}$. Por outro lado, as preocupações com os cuidados infantis eram entendidas como cada vez mais relevantes ${ }^{42}$.

Os restantes anúncios foram o de uma confeitaria do Porto - a Confeitaria Oliveira, com dois estabelecimentos, um na praça Carlos Alberto, 105 e outro na rua 31 de Janeiro, 183 - que se definiu como "casa esmerada na confeção de todos os seus artigos, com primoroso serviço de chá nas suas casas. Restaurante de finíssima ordem"43; o de um armazém de mercearia e de azeite de Matias, Filhos $\Xi$ Carvalhos, Lda., com sede em Coimbra e uma filial em Vila Nova de Poiares ${ }^{44}$ e o da Companhia da Cerveja de Coimbra

\footnotetext{
39 Braga 2006: 215-225.

40 Miranda 1991: 21-22.

${ }^{41}$ Braga 2004: 38.

42 Vaquinhas e Guimarães 2011: 219.

${ }^{43}$ Ilustração, n. ${ }^{\circ}$ 7, Lisboa, 1 de abril de 1926.

${ }^{44}$ Ilustração, n. ${ }^{\circ}$ 13, Lisboa, 1 de julho de 1926.
} 
que informou produzir dois tipos de cerveja - Pilsener e preta - e esclareceu que as mesmas eram "rivais das estrangeiras fabricadas com malte e lúpulo de qualidade escolhidas pelo acreditado técnico da Bohemia A. Springer" ${ }^{45}$.

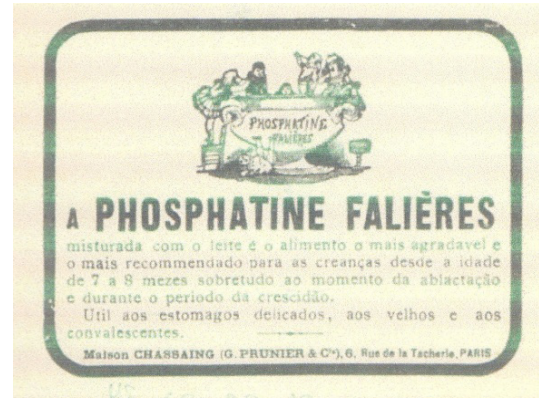

Figura 3: Primeiro anúncio da farinha alimentar Phosphatine Falières Fonte: Ilustração, n. ${ }^{\circ}$ 11, Lisboa, 1 de junho de 1926.

No ano seguinte, o panorama não se alterou substancialmente: 20 anúncios, 15 dos quais da referida farinha Phosphatine Falières, um do Café Chiado, em Lisboa, e quatro de chá da marca Horniman, de página inteira e com duas figuras orientais.

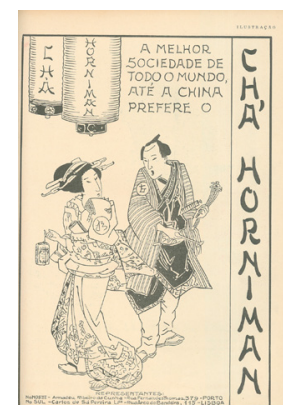

Figura 4: Primeiro anúncio do chá Horniman

Fonte: Ilustração, n. ${ }^{\text {45, de }} 1$ de novembro de 1927.

O ano de 1928 trará uma novidade interessante. A publicação de dois anúncios em castelhano, um de uma cervejaria e outro de uma marca de cerveja, ambos de Badajoz. No primeiro apresentava-se o American Bar: "la mejor cerveza del mundo se bebe en esta cerveceria de esmerado servicio y frequentada por las personas mas distinguidas" ${ }^{46}$, no segundo era a Cerveza

\footnotetext{
45 Ilustração, n. ${ }^{\circ}$ 13, Lisboa, 1 de julho de 1926.

${ }^{46}$ Ilustração, n. ${ }^{\circ}$ 62, Lisboa, 16 de junho de 1928.
} 
de Herena que agradaria aos forasteiros, de tal modo que "en los cafés, bares y restaurantes sempre Cerveza de Herena sera el grato recuerdo de Badajoz" ${ }^{47}$. Recorde-se que a Ilustração era vendida em Espanha e que no preciso número em que apareceram estes dois anúncios foi publicado um artigo sobre Badajoz, igualmente em castelhano, da autoria de um advogado e presidente da assembleia da imprensa daquela cidade.

No mesmo ano, a Nestlé deu a conhecer o seu primeiro anúncio na revista. Foi relativo ao leite condensado Moça e a uma farinha láctea e, no mesmo, remeteu para uma pequena notícia da Ilustração, dedicada a questões mundanas. Foi uma forma de reforçar as qualidades do produto, uma vez que apresentou três crianças gémeas negras que haviam sido abandonadas na selva, salvas por um missionário e alimentadas com o referido leite condensado, as quais pareciam estar bem nutridas ${ }^{48}$. A Nestlé incluirá ainda um outro anúncio de página inteira aos mesmos produtos, num outro número da revista ${ }^{49}$.

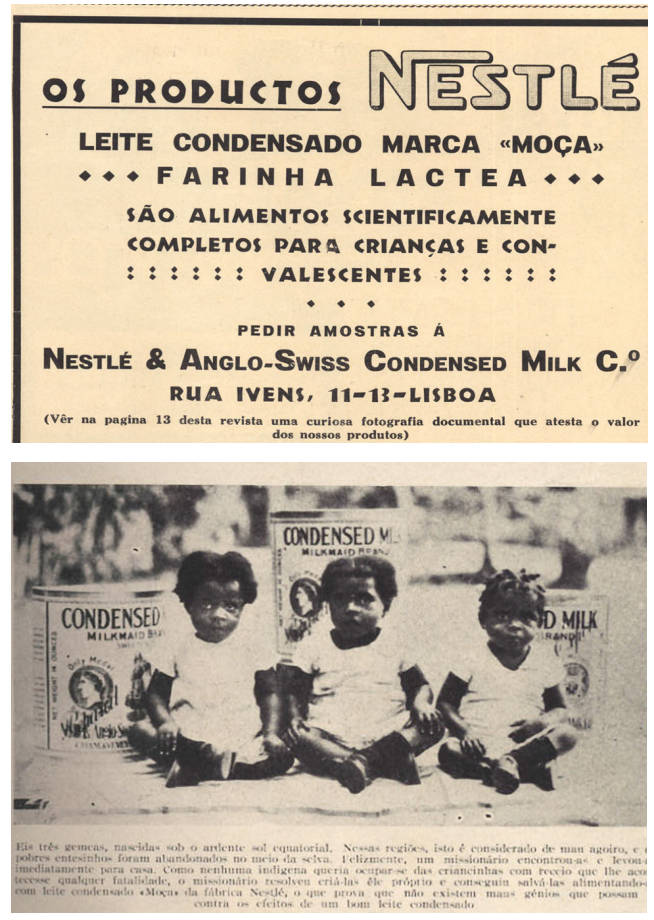

Figura 5 e 6: Anúncio ao leite condensado Moça da Nestlé e fotografia de três crianças africanas criadas por um missionário que as alimentou com o referido leite.

Fonte: Ilustração, n. ${ }^{\circ}$ 62, Lisboa, 16 de junho de 1928.

\footnotetext{
47 lustração, n. ${ }^{\circ}$ 62, Lisboa, 16 de junho de 1928.

${ }^{48}$ Ilustração, n. ${ }^{\circ}$ 62, Lisboa, 16 de junho de 1928.

${ }^{49}$ Ilustração, n. ${ }^{\circ}$ 72, Lisboa, 16 de dezembro de 1928.
} 
Teremos ainda o primeiro anúncio relativo à margarina Vaqueiro, importada pela empresa Jerónimo Martins E Filho, que, curiosamente, recorre a um modelo masculino negro, com expressão bizarra, para a dar a conhecer ao público da Ilustração.

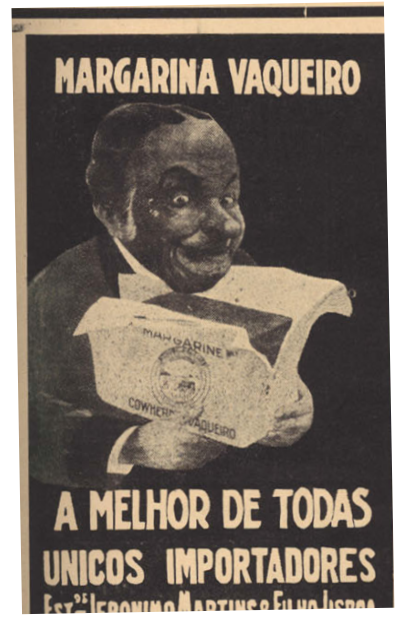

Figura 7: Anúncio relativo à margarina Vaqueiro

Fonte: Ilustração, n. ${ }^{\circ}$ 64, Lisboa, de 16 de agosto de 1928.

Os chocolates, dedicados às crianças, apareceram igualmente no final de 1928. Foram publicados dois anúncios, da Tobler, o primeiro integrando uma imagem com três crianças a contemplarem com curiosidade e interesse o produto e o segundo, de página inteira, com uma mãe e uma criança em atitude carinhosa e os referidos chocolates. Em ambos, refere-se que foram fabricados na Suíça, ao mesmo tempo que se salienta o valor nutricional e se referem os locais de venda: as confeitarias.

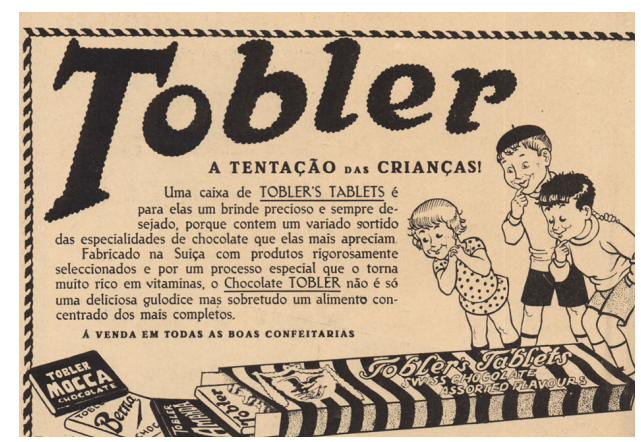

Figura 8: Primeiro anúncio ao chocolate Tobler, dedicado às crianças Fonte: Ilustração, n. ${ }^{\circ}$ 71, de 1 de dezembro de 1928. 
Neste ano, voltará a publicidade ao chá Horniman. Com dois anúncios de página inteira, um com imagens do Parlamento britânico e o outro do comboio Flying Scotsman. Os anúncios incluíram uma pequena história do edifício e do meio de transporte, bem como a referência ao chá consumido na Grã-Bretanha há mais de $100 \operatorname{anos}^{50}$. No ano seguinte, isto é, em 1929, foram publicados 26 anúncios de produtos alimentares, referentes a cinco marcas diferentes. A primazia, com 14, coube à Nestlé que insistiu no leite condensado açucarado e na farinha láctea. As imagens utilizadas foram, contudo, mudando. Apareceram anúncios de página inteira e outros de parte de uma página. Todos incluíram crianças e embalagens a par de indicações acerca das vantagens da utilização do leite condensado face ao leite fresco, designadamente a maior higiene ${ }^{51}$. Encontram-se ainda anúncios com fotografias de crianças gémeas alimentadas com os produtos Nestlé. O chá Horniman, com seis, continuou a dar a conhecer os vários ambientes ingleses onde o produto era consumido e apreciado, desta feita, após a frequência de estádios de futebol, do lord mayor show, durante os voos Londres-Paris, a bordo do Astúrias, em passeios pelo rio Tamisa e no Banco de Inglaterra. O chocolate Tobler repetiu a imagem do ano anterior, as crianças a contemplarem o produto, e apareceu três vezes. Já a margarina Vaqueiro publicou dois anúncios, um dos quais inaugurou uma prática corrente nos anos seguintes, a de apresentar um texto denso com muita informação acerca das vantagens nutricionais do produto, aproximando a matéria alimentar das questões médicas. No caso em apreço, trata-se de um extenso parecer do químico Charles Lepierre que exaltou as qualidades da margarina face à manteiga ${ }^{52}$. Finalmente, um pequeno anúncio do café $H a g$, descafeinado mas que não era cevada, segundo o anunciante ${ }^{53}$.

Em 1930, não estiveram presentes na revista os anúncios a produtos lácteos da Nestlé, mas uma nova farinha marcou presença 14 vezes: a Maizena, destinada a crianças e adultos e acompanhado com um texto explicativo longo. Também desapareceu o chocolate Tobler, mas passou a ser anunciado, por três vezes, o Toblerone "chocolate de leite suíço com mel e amêndoa, o mais saboroso e nutritivo" 54 . Finalmente, apareceu ainda um novo produto, o champagne Piper-Heidsieck.

\footnotetext{
${ }^{50}$ Ilustração, n.o 71, Lisboa, 1 de dezembro de 1928 e n. ${ }^{\circ}$ 72, 16 de dezembro de 1728.

51 Sobre os problemas de higiene e de falsificação do leite, cf. Braga 2004: 39-55.

${ }^{52}$ Ilustração, n. ${ }^{\circ}$ 76, Lisboa, 16 de fevereiro de 1929.

53 Ilustração, n. ${ }^{\circ}$ 83, Lisboa, 1 de junho de 1929.

${ }^{54}$ Ilustração, n. ${ }^{\circ}$ 97, Lisboa, 1 de janeiro de 1930.
} 


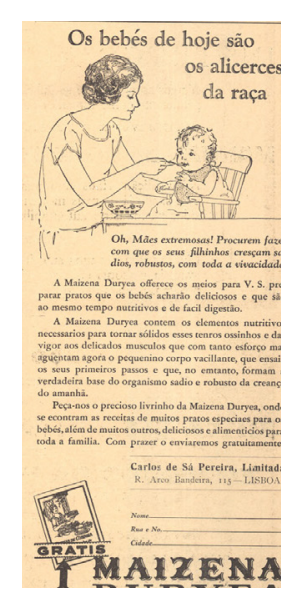

Figura 9: Primeiro anúncio à farinha Maizena

Fonte: Ilustração, n. ${ }^{\circ} 102$, de 16 de março de 1930.

Em 1931, deu-se uma explosão da publicidade relativa a produtos e serviços ligados à alimentação: 84 anúncios de 14 marcas diferentes. As bolachas Nacional publicaram 18, a Ovomaltine 12, a Maizena e a Farinha de São Bento 11 cada, a Allenburys, um alimento lácteo, ficou-se pelos 10, o chá Horniman pelos nove, enquanto os restantes anunciantes foram mais discretos: o chocolate e a farinha Nestlé, bem como o Moscatel de Setúbal, dois cada, enquanto a Vaqueiro investiu apenas em um, de página inteira, focado numa dona de casa, naturalmente o alvo. Trata-se de um anúncio bastante mais adequado do que o primeiro. O vinho do Porto Calém, tal como as pastelarias lisboetas Bénard, Ferrari e Marques deram-se a conhecer no final do ano.

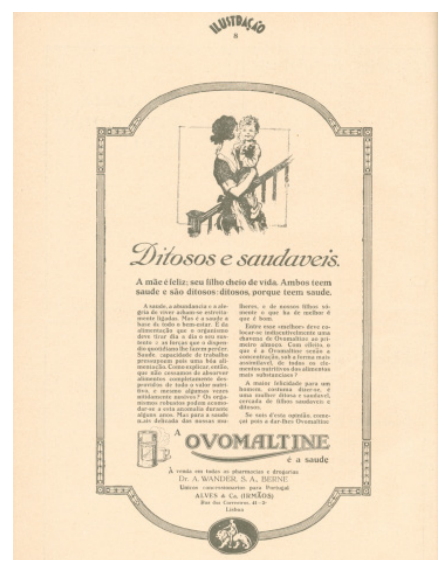

Figura 10: Primeiro anúncio da Ovomaltine, com recurso a um texto denso e explicativo sobre o produto

Fonte: Ilustração, n. ${ }^{\circ}$ 121, Lisboa, 1 de janeiro de 1931. 


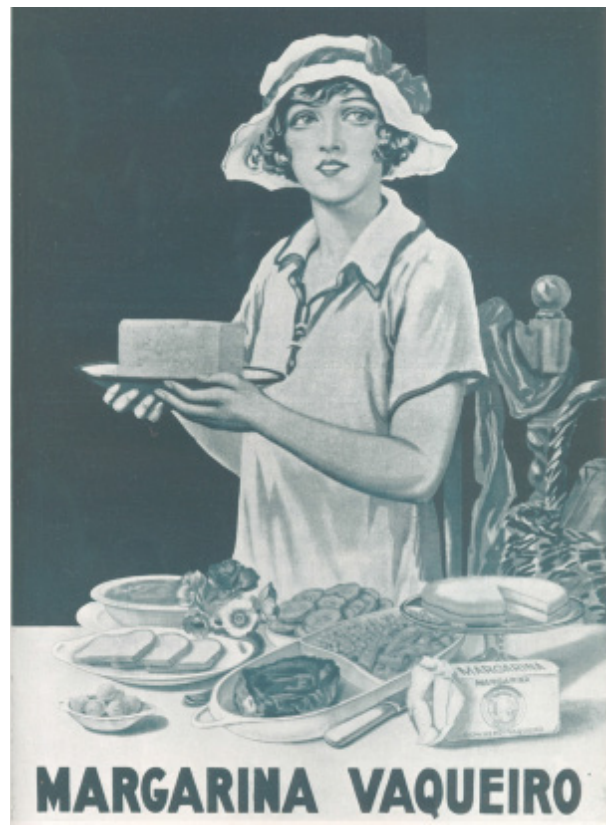

Figura 11: Anúncio da margarina Vaqueiro

Fonte: Ilustração, n.o 144, Lisboa, 15 de dezembro de 1931.

Em 1932, o número de anúncios da temática em estudo baixou. Foram publicados 46, relativos a cinco marcas diferentes. As bolachas Nacional ficaram em primeiro lugar com 21, em segundo o chá Horminan com nove, a Ovomaltine com oito, em alguns casos incluindo desenhos, em outros fotografias; seguindo-se a farinha Maizena e por fim os produtos lácteos Allenburys. No ano seguinte, isto é, em 1933, a publicidade relativa a bens e serviços alimentares diminuiu de novo: 37 anúncios de seis marcas. Liderou a Ovomaltine, com 15, tendo o chá Horminan ficado novamente em segundo lugar com seis anúncios, agora mais pequenos e mais discretos; os produtos Allenburys, com cinco e a farinha Nestlé com dois. Porém registaram-se duas novidades, a entrada dos Corn Flakes da Kellogg's, com sete anúncios e da pastelaria $A$ Brasileira, com apenas dois. 


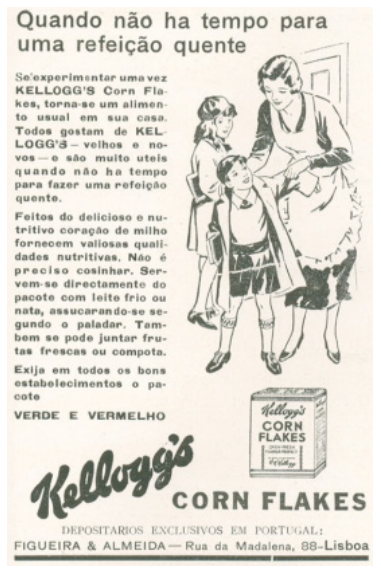

Figura 12: Primeiro anúncio dos Corn Flakes da Kellogg's

Fonte: Ilustração, n. ${ }^{\circ}$ 179, Lisboa, 1 de junho de 1933.

Em 1934, a Ilustração registou 40 anúncios da matéria em estudo, mas os mesmos abrangeram apenas três marcas: a Ovomaltine com 16, a Kellogg's com 14 e a Maizena com 10. No ano seguinte, a situação foi impar: 10 anúncios todos da Ovomaltine, o mesmo acontecerá em 1937, dessa vez um por cada número da revista. Em 1936, a situação foi diferente: 11 anúncios, seis da farinha láctea Nestlé, quatro da Ovomaltine e um dos espumantes Raposeira. Em 1938, foram publicados nove: oito da Ovomaltine e um do Instituto do Vinho do Porto. Seriam os últimos, pois no derradeiro ano de publicação da revista, em 1939, nenhum saiu sobre o tema em estudo.

Face a 350 anúncios de bens e serviços alimentares, percebe-se que não estamos perante uma enorme variedade de marcas. Note-se que apesar da importância de vinhos, azeites, conservas de peixe e da moagem, em geral, no Portugal dessa época, os anúncios não refletiram essa realidade. Uma parte dos produtos era importada, caso dos chocolates, de parte das farinhas lácteas e dos cereais de pequeno-almoço. Esporadicamente, um ou outro vinho português, alguma farinha e as bolachas Nacional, exaltaram a produção do país. De qualquer modo, importa realçar que foram os produtos destinados às crianças - leite, farinha láctea, cereais para juntar ao leite - que se destacaram de forma redundante, com 230 anúncios, os quais representaram 65,7 por cento do total, evidenciando as referidas preocupações com a alimentação infantil. No que se refere aos estabelecimentos, apresentaram baixas percentagens no global, nenhum se tendo destacado ao longo dos anos. Foram anunciados as confeitarias Oliveira (1926), Bénard (1931), Ferrari (1931), Marques (1931) e a Brasileira (1933), o café Chiado (1927), a cervejaria American Bar (1928), sem esquecer o armazém Matias, Filhos \& Carvalhos, Lda. (1926), e ainda a Companhia de Cerveja de Coimbra (1926) e o Instituto do Vinho do Porto (1938). 
Isabel M. R. Mendes Drumond Braga

\begin{tabular}{|c|c|c|c|c|c|c|c|c|c|c|c|c|c|c|c|}
\hline Ano & 1926 & 1927 & 1928 & 1929 & 1930 & 1931 & 1932 & 1933 & 1934 & 1935 & 1936 & 1937 & 1938 & 1939 & Total \\
\hline Phosphatine & 13 & 15 & - & - & - & - & - & - & - & - & - & - & - & - & 28 \\
\hline Horniman & - & 4 & 2 & 6 & - & 9 & 9 & 6 & - & - & - & - & - & - & 36 \\
\hline Herena & - & - & 1 & - & - & - & - & - & - & - & - & - & - & - & 1 \\
\hline Nestlé & - & - & 2 & 14 & - & 2 & - & 2 & - & - & 6 & - & - & - & 26 \\
\hline Vaqueiro & - & - & 1 & 2 & - & 1 & - & - & - & - & - & - & - & - & 4 \\
\hline Tobler/Toblerone & - & - & 2 & 3 & 3 & 2 & - & - & - & - & - & - & - & - & 10 \\
\hline Maizena & - & - & - & - & 14 & 11 & 6 & - & 10 & - & - & - & - & - & 41 \\
\hline Hag & - & - & - & 1 & - & - & - & - & - & - & - & - & - & - & 1 \\
\hline Pier-Heidsieck & - & - & - & - & 1 & - & - & - & - & - & - & - & - & - & 1 \\
\hline Nacional & - & - & - & - & - & 18 & 21 & - & - & - & - & - & - & - & 39 \\
\hline Ovomaltine & - & - & - & - & - & 12 & 8 & 15 & 16 & 10 & 4 & 24 & 8 & - & 97 \\
\hline Farinha São Bento & - & - & - & - & - & 11 & - & - & - & - & - & - & - & - & 11 \\
\hline Moscatel Setúbal & - & - & - & - & - & 2 & - & - & - & - & - & - & - & - & 2 \\
\hline Porto Calém & - & - & - & - & - & 1 & - & - & - & - & - & - & - & - & 1 \\
\hline Allenburys & - & - & - & - & - & 10 & 2 & 5 & - & - & - & - & - & - & 17 \\
\hline Kellogg's & - & - & - & - & - & - & - & 7 & 14 & - & - & - & - & - & 21 \\
\hline Raposeira & - & - & - & - & - & - & - & - & - & - & 1 & - & - & - & 1 \\
\hline Total & 13 & 19 & 8 & 26 & 18 & 79 & 46 & 35 & 40 & 10 & 11 & 24 & 8 & 0 & 337 \\
\hline
\end{tabular}

Quadro 3: Marcas de Géneros Alimentares na Ilustração (1926-1939)

Outros anúncios, que não publicitam nem alimentos nem serviços relativos às práticas alimentares, não deixam de tocar a temática, caso por exemplo dos que se referiram a fogões, a frigoríficos e a livros de cozinha, como os que se podem ver em seguida. No caso dos primeiros apareceram vários modelos, no que se refere aos segundos, o que inaugurou o assunto datou de 1928, no dos terceiros temos os Doces e Cozinhados, de Isalita, primeiro com anúncios de página inteira e, posteriormente, com outros bastante mais pequenos ${ }^{55}$.

55 Em 1928, o anúncio da obra de Isalita, com a imagem do livro, passará a indicar o preço do mesmo, isto é, 25\$00. Cf. Ilustração, n. o 54, Lisboa, 16 de março de 1928. 
Anunciar alimentos e seduzir consumidores: a publicidade na revista Ilustração (1926-1939)

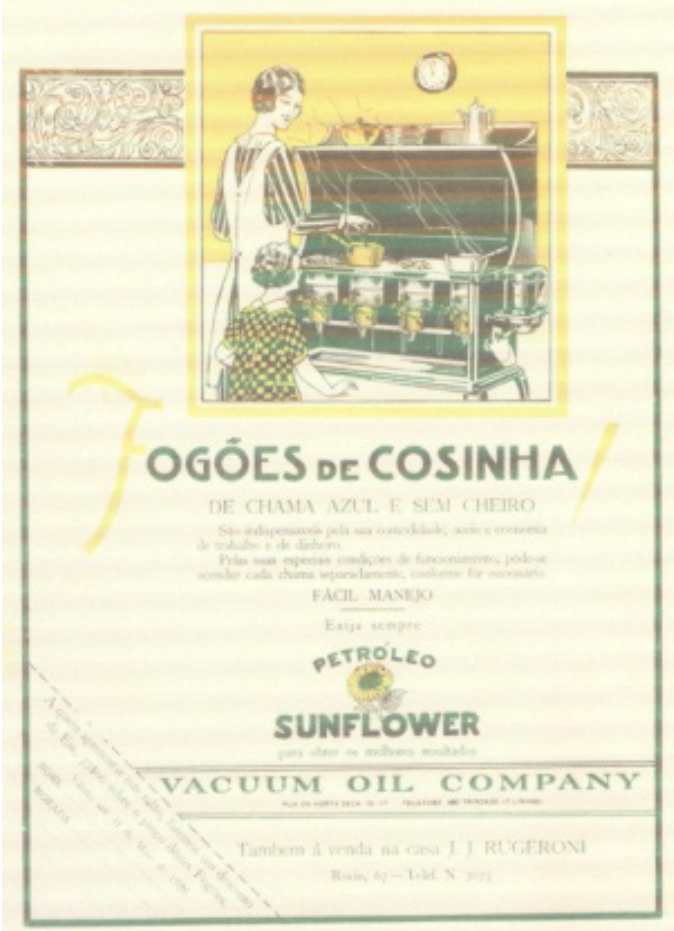

Figura 13: Anúncio de fogões de cozinha com talão de desconto no valor de $35 \$ 00$, sobre o preço total do aparelho que não foi indicado

Fonte: Ilustração, n. ${ }^{\circ}$ 9, Lisboa, 1 de maio de 1926.

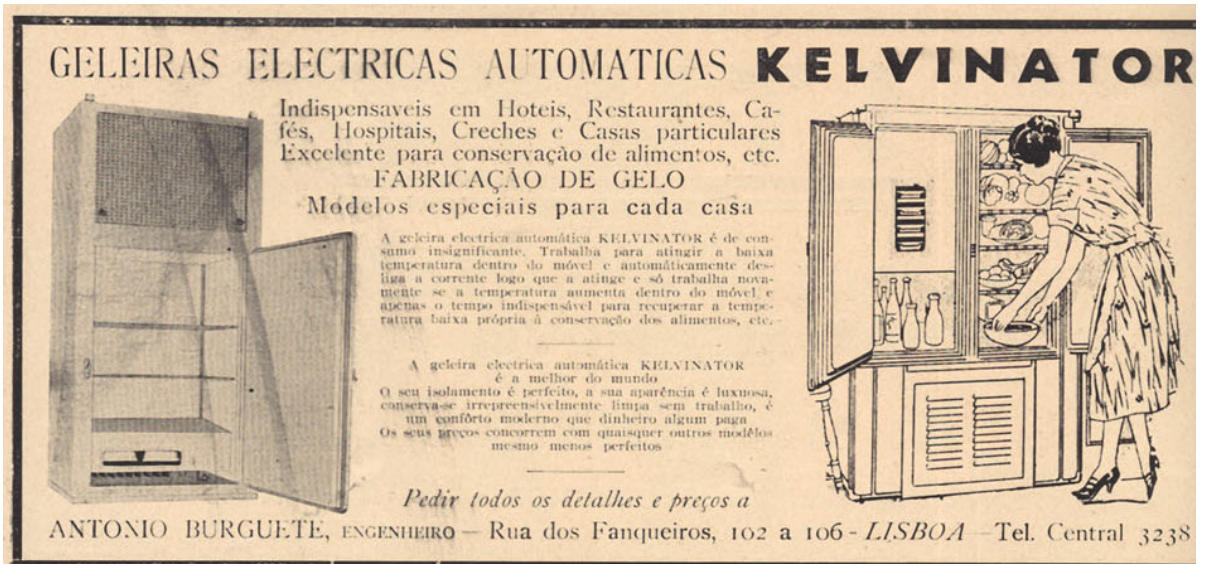

Figura 14: Primeiro anúncio a um frigorífico

Fonte: Ilustração, n. ${ }^{\circ}$ 60, de 16 de junho de 1928. 


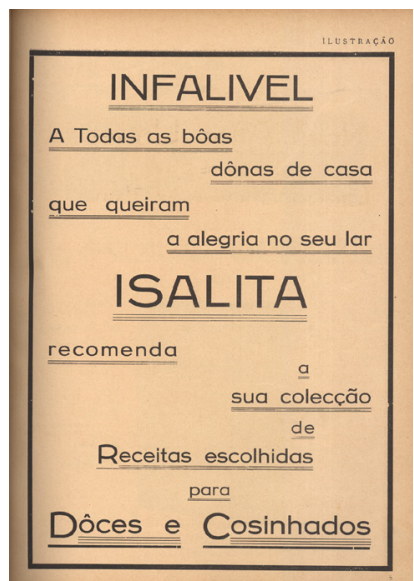

Figura 15: Anúncio relativo à obra de Isalita, Doces e Cozinhados Fonte: Ilustração, n. ${ }^{\circ}$ 27, de 1 de fevereiro de 1927.

De referir que a publicidade relativa aos eletrodomésticos foi incluindo enceradoras, esquentadores, fogões, frigoríficos e até máquinas de lavar roupa, muito embora o consumo desses bens estivesse muito longe de ser generalizado, o que mais uma vez nos remete para o público dessa revista. Efetivamente, se o eletrodoméstico que mais revolucionaria a arte de cozinhar na segunda metade do século XX foi o frigorífico, movido inicialmente a vapor, depois a petróleo, a gás e, por fim, a eletricidade, os primeiros aparelhos começaram por ser utilizados para fins industriais ou em estabelecimentos comerciais ainda antes da I Guerra Mundial. No final da década de vinte, apareceram os primeiros frigoríficos elétricos para uso doméstico. Contudo, no final dos anos trinta, em Lisboa, apenas existiam 50 aparelhos, a maioria dos quais pertencentes a estabelecimentos comerciais e industriais ${ }^{56}$. Será a partir do final da II Guerra Mundial que os eletrodomésticos irão entrar de forma cada vez mais significativa nos lares portugueses.

Finalmente, mais algumas chamadas de atenção para o modo como se anunciavam os produtos, embora sem qualquer abordagem do tipo quantitativo e sem questionamentos acerca da validade da abordagem proposta por Rui Estrela, que criou uma tipologia, entendendo que a publicidade podia assumir vários estilos ${ }^{57}$, designadamente: estilo informativo, caracterizado por uma atitude passiva face ao consumidor, não apelando a qualquer comportamento, caso, por exemplo, dos anúncios das bolachas Nacional; estilo comparativo, no qual se comparam produtos, face à concorrência ou se utilizam superlativos,

\footnotetext{
56 Marques 1991: 625.

57 Estrela 1, 2002: 36-44.
} 
como o mais, o melhor e outros. Tal é o caso de alguns da Ovomaltine, da Vaqueiro e da Nestlé; estilo atmosférico, caracterizado por tentar evocar uma imagem ou uma disposição associada ao produto de modo a fomentar o seu consumo, por exemplo alguns da Ovomaltine, para facilitar um sono tranquilo; estilo de execução, baseado no conhecimento técnico, demonstrando a experiência ou o conhecimento especializado da empresa na elaboração do produto. Nesta tipologia enquadram-se os anúncios a produtos lácteos, designadamente alguns da Nestlé e da Maizena (veja-se o caso da Figura 9).

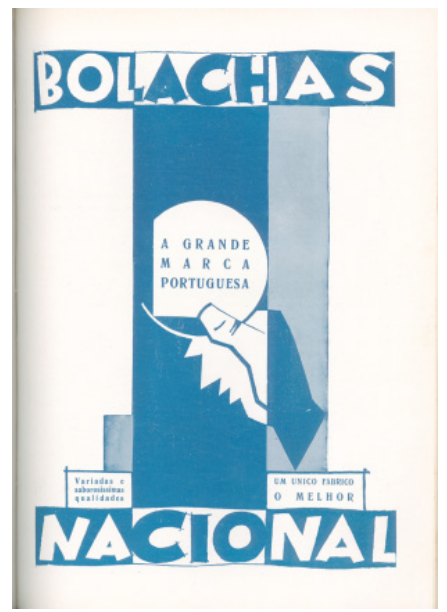

Figura 16: Anúncio de tipo informativo das bolachas Nacional Fonte: Ilustração, n. ${ }^{\circ}$ 20, Lisboa, 16 de outubro de 1932.

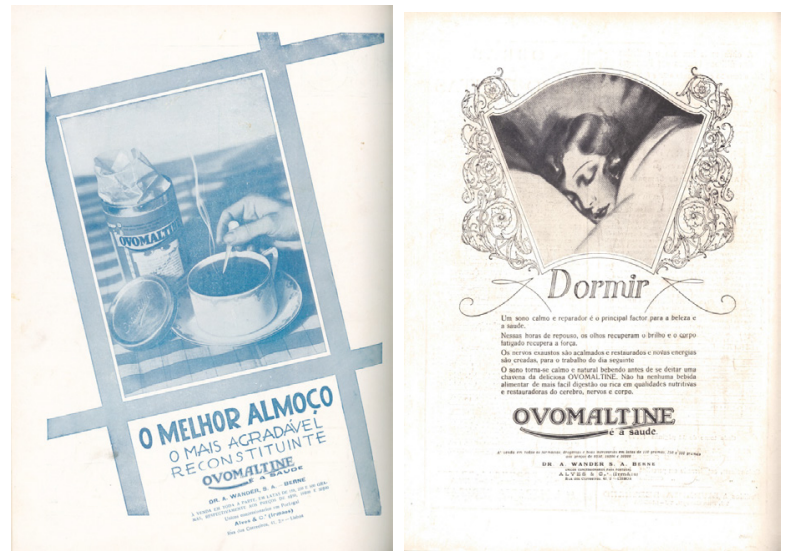

Figura 17 e 18: Anúncios dos tipos comparativo e atmosférico da Ovomaltine Fonte: Ilustração, n. ${ }^{\circ}$ 20, Lisboa, 16 de outubro de 1932 e n. ${ }^{\circ}$ 202, Lisboa, 16 de maio de 1934, respectivamente. 
A revista Ilustração, tal como tantas outras anteriores e posteriores, cumpriu cabalmente as suas missões de informar e transmitir conhecimentos. Mas fez mais do que isso, difundiu de forma acessível um conjunto de dados a letrados e iletrados ${ }^{58}$, ensinou e tentou disciplinar os seus leitores, formando opiniões e gostos, fornecendo normas de comportamento e incentivando ao consumo de bens e serviços das mais variadas áreas, através dos artigos e da publicidade, que constituía, certamente, também uma relevante fonte de receita. A leitura das várias seções da Ilustração e dos anúncios permitiu aos leitores a obtenção de referentes para, desse modo, exercerem mais corretamente as suas funções sociais ${ }^{59}$. Pensemos, por exemplo, para nos limitarmos à temática em estudo, nas extensas informações acerca das características dos produtos lácteos, da importância do seu uso entre crianças e adultos, sãos, doentes e convalescentes, e até dos suplementos alimentares, não designados dessa maneira. E pensemos também nas relações óbvias e nas subliminares patenteadas entre produtos como chocolates, farinhas e leites, por um lado, e afetividade maternal, saúde, sono tranquilo e, em última instância, bem-estar das famílias.

\section{REFERÊNCIAS}

\section{Fontes Impressas}

Ilustração, n. 1-336, Lisboa, 1926-1939.

Soares, F. (1934), Guia de Hotéis e Turismo em Portugal, Livraria J. Rodrigues, Lisboa.

\section{Estudos}

Acciaiuoli, M. (2013), António Ferro. A Vertigem da Palavra. Retórica, Politica e Propaganda no Estado Novo, Bizâncio, Lisboa.

Art (L') dans la Pub (2000), Musée de la Publicité, Paris.

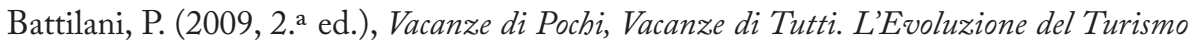
Europei, Il Mulino, Bolonha.

Bargiel, R. (2004), 150 Ans de Publicité, Musée de la Publicité, Paris.

Belo, A. (2001), As Gazetas e os Livros. A Gazeta de Lisboa e a vulgarização do Impresso (1715-1760), Instituto de Ciências Sociais, Lisboa.

Borsay, P. (2006), A History of Leisure. The British Experience since 1500, Palgrave Macmillan, Hampshire, Nova York.

Braga, I. M. R. M. D. (2000), Portugal à Mesa. Alimentação, Etiqueta e Sociabilidade (1800-1850), Hugin, Lisboa.

\footnotetext{
58 Sobre esta temática, já para o século XIX, cf. Cascão 2011: 229.

59 Sobre esta matéria, cf. os considerandos de Pinsky 2014: 10, 46, passim.
} 
Braga, I. M. R. M. D. (2001), “As Realidades Culturais”, in J. Serrão, A.H. de O.Marques (dir.), Nova História de Portugal, vol. 11, Presença, Lisboa, 465-565.

Braga, I. M. R. M. D. (2001),"Medicina Popular versus Medicina Universitária no Portugal de D. João V", in Assistência, Saúde Pública e Prática Médica em Portugal. Séculos XV-XIX, Universitária Editora, Lisboa.

Braga, I. M. R. M. D. (2007), "Alimentação e Publicidade Alimentar na Revista ABC (1920-1926)", in Turres Veteres IX - História da Alimentação, Colibri, Lisboa, 215-225.

Braga, I. M. R. M. D. (2015), "Culinária e Etiqueta em Portugal nos Anos 30: as Propostas de Estela Brandão", in Patrimónios Alimentares de Aquém e Além Mar, Imprensa da Universidade de Coimbra, Annablume, Coimbra, 591-610.

Braga, I. M. R. M. D. (2008), “Culinária no Feminino: Os Primeiros Livros de Receitas Escritos por Portuguesas”, Caderno Espaço Feminino 19.1: 117-141.

Braga, I. M. R. M. D. (2010), Sabores do Brasil em Portugal. Descobrir e Transformar novos Alimentos (séculos XVI-XXI), Editora Senac de São Paulo, São Paulo.

Braga, I. M. R. M. D. (2012) "Medicina, Higiene e Cosmética na Publicidade do Jornal Badaladas: 1948-1958", in História da Saúde e das Doenças. Turres Veteras XIV, Universidade de Lisboa, Lisboa, Colibri, Torres Vedras, Município de Torres Vedras, 57-72.

Braga, I. M. R. M. D. (2015), “A Culinária Portuguesa no Tempo da II Guerra Mundial: as Receitas, o Racionamento e as Soluções Alternativas", Revista de História Helikon 2.3: 1-23.

Braga, I. M. R. M. D., Oliveira, R. P. de (2008), "Seduzir para Vender: Para o Estudo da Publicidade em São Miguel no século XIX", in O Liberalismo nos Açores: Do Vintismo à Regeneração. O Tempo de Teotónio de Ornelas Bruges (1807-1870). Actas do Colóquio, Instituto Açoriano de Cultura, Angra do Heroísmo, 415-436.

Braga, P. D. (2004), Leite. Biografia de um Género Alimentar, Colares Editora, Sintra.

Campos, R.D. de (2009), Mulheres e Crianças na Imprensa Paulista (1920-1940). Educação e História, Editora Unesp, São Paulo.

Capatti, A., Montanari, M. (2002), La Cuisine Italienne. Histoire d'une Culture, Seuil, Paris.

Cascão, R. (2011), "Em Casa. O Quotidiano Familiar”, in J. Mattoso (dir.), História da Vida Privada em Portugal 3, Círculo de Leitores, Lisboa, 222-252.

Chartier, R. (1987), Lectures et Lecteurs dans la France de l'Ancien Régime, Seuil, Paris.

Chartier, R. (1996), Culture Écrite et Société. L'Ordre des Livres (XIV-XVII' siècle), Albin Michel, Paris.

Chartier, R. (1990), "As Práticas da Escrita", in Ph. Ariès, G. Duby (dir.), História da Vida Privada 3, Afrontamento, Porto, 113-161.

Cytrynowicz, R. (2000), Guerra sem Guerra. A Mobilização e o Cotidiana em São Paulo durante a Segunda Guerra Mundial, EDUSP, São Paulo.

Corner, P. (2015), Italia Fascista. Politica e Opinione Popolare sotto la Dittadura, Carocci Editore, Roma. 
Dias, V. (2005), “Helena Augusta Teixeira de Aragão Breia”, in Z. O. de Castro, J. Esteves (dir.), Dicionário no Feninino (séculos $X I X-X X$ ), Livros Horizonte, Lisboa, 385.

El-Kareh, A. C., Bruit, H. H. (2004), “Cozinhar e Comer, em Casa e na Rua: Culinária e Gastronomia na Corte do Império do Brasil”, Estudos Históricos 33:1-23.

Estrela, R. (2002-2004), A Publicidade no Estado Novo, 2, Simplesmente Comunicando, Lisboa.

Faraldo, J. M., Rodríguez-López, C. (2013), Introducción a la Historia del Turismo, Alianza Editorial, Madrid.

García, H. (2006), "El Turismo Político durante la Guerra Civil: Viajeros Británicos y Técnicas de Hospitalidad en la España Republicana (1936-1939)", Ayer 64.4: 287-308.

Gibert, M. (2009), A Segunda Guerra Mundial, tradução, Publicações D. Quixote, Lisboa.

Gomes, T. V. A. (2011), Uma Revista Feminina em Tempo de Guerra: o Caso da "Eva" (1939-1945), Dissertação de Mestrado em História Contemporânea: Economia, Sociedade e Relações Internacionais apresentada à Faculdade de Letras da Universidade de Coimbra, Coimbra.

Helstosky, C. (2004), Garlic and Oil: Politics and Food in Italy, Berg, Oxford, New York.

Lousada, M. A. (2010) “Viajantes e Turistas. Portugal, 1850-1926”, in Viajar. Viajantes e Turistas à Descoberta de Portugal no Tempo da Primeira República, Comissão Nacional para as Comemorações do Centenário da República, Turismo de Portugal, Lisboa, 65-75.

Segundo Leilão Vista Alegre (1998), Estar, Lisboa.

Terceiro Leilão Vista Alegre (1999), Estar, Lisboa.

Quarto Leilão Vista Alegre (2000), Estar, Lisboa.

Quinto Leilão Vista Alegre (2002), Estar, Lisboa.

Sexto Leilão Vista Alegre (2003), Estar, Lisboa.

Sétimo Leilão Vista Alegre (2004), Estar, Lisboa.

Oitavo Leilão Vista Alegre (2007), Estar, Lisboa.

Nono Leilão Vista Alegre (2009), Estar, Lisboa.

MacDonogh, G. (2007), After the III Reich. The Brutal History of the Allied Occupation, Basic Books, Nova Iorque.

Mafai, M. (2008, 7. a ed.), Pane Nero. Donne e Vita Quotidiana nella Seconda Guerra Mondiale, Ediesse, Roma.

Marques, A. H. de O. (1981), Guia de História da 1. a República Portuguesa, Estampa, Lisboa.

Marques, A. H. de O. (1991a), “A Conjuntura”, in J. Serrão, A. H. de O. Marques (dir.), Nova História de Portugal, vol. 11, Presença, Lisboa, 709-717.

Marques, A. H. de O. (1991b), “Aspectos da Vida Quotidiana”, in J. Serrão, A. H. de O. Marques (dir.), Nova História de Portugal, vol. 11, Presença, Lisboa, 617-677.

Marques, A. H. de Oliveira (1991c), “Escolas e Ensino”, in J. Serrão, A. H. de O. Marques (dir.), Nova História de Portugal, vol. 11, Presença, Lisboa, 519-520. 
Martinez, P. S. (2001), A República Portuguesa e as Relações Internacionais (1910-1926), Verbo, Lisboa.

Martins, A. L. (2001), Revistas em Revista. Imprensa e Práticas Culturais em Tempos da República. São Paulo (1890-1922), EDUSP, São Paulo.

Melo, D. (2001), Salazarismo e Cultura Popular (1933-1958), Instituto de Ciências Sociais, Lisboa.

Meneses, F. R. (2010, 2. ed.), Salazar. Uma Biografia Política, tradução de Teresa Cabral, D. Quixote, Lisboa.

Menezes, L.M. (2008), “A Imigração nos Anúncios de Jornais do Rio de Janeiro: Facetas Parisienses do Sonho Civilizatório”, in M. L. Lessa, S. C. P. de B. Fonseca (org.), Entre a Monarquia e a República. Imprensa, Pensamento Político e Historiografia (1822-1889), EdUERJ, Rio de Janeiro, 221-242.

Miranda, S. (1991), “A Base Demográfica”, in J. Serrão, A. H. de O. Marques (dir.), Nova História de Portugal, vol. 11, Presença, Lisboa, 21-22.

Mota-Ribeiro, S. (2002), "Corpos Eróticos: Imagens da Mulher na Publicidade da Imprensa Feminina Portuguesa”, Cadernos do Nordeste 17.1-2: 145-164.

Moulin, L. (1989), Les Liturgies de la Table: Une Histoire Culturelle du Manger et du Boire, Albin Michelle, Paris.

Nunes, A. B., Brito,J.M. B. (1992), "Política Económica, Industrialização e Crescimento”, in J. Serrão, A. H. de O.Marques (dir.), Nova História de Portugal, vol.12, Editorial Presença, Lisboa, 319-321.

Ó, J. R. (1991), "Salazarismo e Cultura”, in J. Serrão, A. H. de O. Marques (dir.), Nova História de Portugal, vol. 12, Editorial Presença, Lisboa, 391-454.

Ó, J. R. (1999), Os Anos de Ferro. O Dispositivo Cultural durante a Politica do Espirito. 1933-1949, Estampa, Lisboa.

Oliveira, A. L. (1981), Dicionário de Mulheres Célebres, Lello \& Irmão Editores, Porto.

Oliveira, P. A. (2011), “A República e a Guerra, 1914-1918”, in L. Amaral (coord.), Outubro: a Revolução Republicana em Portugal (1910-1926), Edições 70, Lisboa, 185-225.

Parker, R. A. C. (1989), História da Segunda Guerra Mundial, Edições 70, Lisboa.

Pereira, A. L., Pita, J. R. (1996), “La Publicité Pharmaceutique, Médicale et Cosmétique dans la Revue A Ilustração (Paris, 1884-1892)”, Revue d'Histoire de la Pharmacie 43.309:159-168.

Pereira, A. L., Pita, J. R. (1998), "Publicidade a Cosméticos (séculos XIX-XX)”, Munda 35: 29-40.

Pereira, A. M. P. (1997), O Nu e a Publicidade Audiovisual, Pergaminho, Lisboa.

Pina, P. (1988), Portugal. O Turismo no século XX, Lucidus, Lisboa.

Pita, J. R. (1998), História da Farmácia, Minerva, Coimbra.

Pinsky, C. B. (2014), Mulheres dos Anos Dourados, Contexto, São Paulo.

Pubblicità E̊ Arte. Grafica Internazionale dall'Affiche alla Pop Art (2007), dir. Claudio Salsi, Skira, Milão. 
Publicidade (A) em Portugal através do Bilhete-Postal Ilustrado (1998), Lisboa, Ecosoluções. Publicidade (A) no Azulejo (2004), texto Fernando Bento Gomes, fotografia Jorge Correia Santos, Inapa, Lisboa.

"Reclames"(Os) de Fulvio Pennacchi: Primórdios da Propaganda Brasileira (2005), Instituto de Moreira Salles, São Paulo.

Romero Samper, M. (2013), "Hambre y Retaguardia Protesta Social en la Madrid de la Guerra Civil", Estudios de Seguridad y Defensa 2: 159-190.

Rosas, F. (1994), "Sob os Ventos da Guerra: a primeira crise séria do Regime (19401949)”, in J. Mattoso (dir.), História de Portugal, vol. 7, Editorial Estampa, Lisboa, 301-415.

Rosas, F. et al. (2009), “A guerra”, in F. Rosas, M. F. Rollo (coord.), História da Primeira República Portuguesa, Tinta-da-China, Lisboa, 245-406.

Segredo, A. M. (2015), Italiani a Tavola. Milleottocentosessenta - Millenovecentosessenta. Storia dell'Alimentazione della Cucina e della Tavola in Italia, Palombi Editori, Roma.

Silva, J. L. M. (2008), Cozinha Modelo, EDUSP, São Paulo.

Soares, E. C. P. de C. (2008), A Gazeta de Lisboa e a Publicidade no século XVIII (17151760), Lisboa, Dissertação de Mestrado em História Moderna apresentada à Faculdade de Letras da Universidade de Lisboa.

Sobral, J. M. (2007), "Nacionalismo, Culinária e Classe. A Cozinha Portuguesa da Obscuridade à Consagração (séculos XIX-XX)”, Ruris 1.2: 13-52.

Tadeu, T. (2007), “A Publicidade n’ A Guarda (1939-1945)”, Revista Portuguesa de História 39: 315-340.

Tengarrinha, J. (1989, 2. ${ }^{a}$ ed.), História da Imprensa Periódica Portuguesa, Caminho, Lisboa.

300 Anos do Cartaz em Portugal (1975-1976), prefácio de A. H. de Oliveira Marques, introdução de Rui Rocha, Biblioteca Nacional, Lisboa.

Trindade, L. (2008), Foi você que pediu uma História da Publicidade, Tinta-da-China, Lisboa.

Vaquinhas, I., Guimarães, M. A. P. (2011), "Economia Doméstica e Governo do Lar. Os Saberes Domésticos e as Funções da Dona de Casa”, in J. Mattoso (dir.), História da Vida Privada em Portugal 3, Círculo de Leitores, Temas \& Debates, Lisboa, 194-221.

Vieira, A. L. (1980), “Os Transportes Rodoviários em Portugal, 1900-1940”, Revista de História Económica e Social 5: 57-94.

Vicio (O) da Liberdade. Colecção Berardo. Arte e Desenhos Publicitários (2003), [s.1.], [s.n]. 